日览腎誌 Vol.24 No.1

\title{
論文タイトル : Angiotensin Receptor Blocker Protection Against Podocyte-Induced Sclerosis Is Podo- cyte Angiotensin II Type 1 Receptor-Independent
}

著

者：Taiji Matsusaka;Takako Asano, Fumio Niimura, Masaru Kinomura, Akihiro Shimizu, Ayumi Shintani, Ira Pastan, Agnes B. Fogo, lekuni Ichikawa

掲 載 誌: Hypertension, Apr $2010 ; 55: 967-973$

紹介者：中村 信也（北里大学医学部小児科）

\section{背景}

我々はアンギオテンシンレセプターブロッカー (ARB) の腎保護効果はポドサイト上のAT 1 レセプ ターに依存しているという仮説のもと研究を行ってい る。そのためにAT 1 gene (Agtra) ノックアウトと NEP 25 〔immunotoxin『抗Tac (Fv)PE38』でポドシン障害を 選択的に引き起こすモデル〕を交配し，ポドサイト特異 的ノックアウトマウスを作成した。注射後 4 週間で Agtr 1 aノックアウト/NEP25マウス群ではNEP25群に 比して尿中アルブミン/クレアチニンが減少しなかった

(8.08in KO vs 4.84 in Control)。両群ともに同様の硬化 （0.66 vs $0.82,0 \sim 4$ 硬化スコアで比較）とネフリンの 減少 $(5.78 \pm 0.45$ vs $5.65 \pm 0.58,0 \sim 8$ scale で比較 $)$ を認めた。

NEP25マウスではAt 1 アンタゴニストあるいはACEI で明らかに蛋白尿は減少し，硬化が軽くなった。ヒドラ ラジンではその現象は見られなかった。

さらにアンギオテンシン II を持続注射すると Agtr $1 \mathrm{a}$ ノックアウト，ワイルドタイプ両者とも微小アルブミン 尿が出現した。

したがって，アンギテンシンの阻害はポドサイトの AT 1 に依存しないでポドサイトを保護し, 系球体硬化 防止につながる。

メカニズムとして, 他の細胞の AT 1 ブロックかAT 1 を介さないメカニズムの存在が考えられる。われわれの 研究はポドサイト障害による硬化は他の細胞を抑えるこ とが有効であることを示唆している。

\section{はじめに}

ポドサイトは糸球体の濾過バリアには必須である。ポ
ドサイトの障害は進行性系球体硬化を引き起こす。この 障害にはアンギオテンシン II (Ang II ) が関与すること が多くの論文で証明されている。ARB やACEI は臨床に おいても，CKDの進行を遅らすことが知られている。 同時に動物モデル（5/6 腎摘モデルや糖尿病モデル） においてはARB やACEIはポドサイトの障害, 蛋白尿, 系球体の硬化の進展を抑えることが知られている。

アンギオテンシンの持続注射では，デスミンの分泌を 増加させ，ネフリンやポドシン mRNA を抑制する。

ポドサイトの障害は系球体障害を引き起こし，Ang II の抑制で，ポドサイトの障害と糸球体障害を抑えられ る。ゆえにポドサイトに扔ける，AT1を介した薬理学 的な Ang II のブロックが有効であると考えることは妥当 かもしれない。ポドサイトにおけるAng II レセプターの 局在，その働きに関する論文が多くみられる。さらに， ポドサイトに選択的に存在するAT1のトランスジェ ニックラットでは糸球体硬化が進行する。これらのデー 夕では糸球体硬化における Ang II のブロックは有益で, それはポドサイトにおける Ang II をブロックによるもの と言える。

最近，われわれはポドサイトにヒトCD25（IL 2 レセ プター）を発現するトランスジェニックマウス（NEP 25）を作成した。ヒトCD25はマウスのIL 2 リガンドに 反応しないため，高濃度の分泌を引き起こす。これにヒ トCD25に対するリコンビナントイムノトキシンである 抗Tac-PE38（LMB 2）を投与するとポドサイトを選択 的に障害する。1 回投与で， $1 \sim 2$ 週間後に中等量の蛋 白尿となり, 以降減少していく。2 週間以内にポドサイ 卜に軽度の変化を認める。3 週間後にポドサイトや他の 細胞に進行性のダメージを与える。AT 1 ノックアウト マウスはAgtr 1aノックアウトモデルを用いた（マウス 
は99\%Agtr 1 a を介するため)。

\section{方法}

ノックアウトマウス交配, 遺伝子識別方法は割愛し た。LMB $2 （ 0.625 \mathrm{ng} / \mathrm{gBW})$ 注射後， 1 週間毎に24時間 尿を採取し，28日で屠殺した。AT 1 ブロッカー使用群 はロサルタン $(0.5 \mathrm{~g} / \mathrm{L}$, DW $)$ を使用。LMB 2 注射 5 日 前より，屠殺まで投与した。コントロールは性別，週数 を同じくしたNEP マウスを用いた。Ang II (1000ng/kg /分）投与はミニオスミックポンプを使用し，14日間連 続投与した。

\section{形態検 査}

PAS 染色を用い, 各々の系球体を評価した。硬化ス コアは 0 が $0 \%, 1$ が 1 25\%，2 が26〜50\%， 3 が51 〜 75\%，4が75\%以上の 5 段階に分類した。

ポドサイトの障害はネフリン染色で評価した。ネフリ ンは, 0 , 消失, 1 , 減少, 2 , 正常とした。

\section{結果}

(1)ポドサイトのAT 1 レセプターの減少が糸球体硬化の 進行を抑えるかどうか

LMB 2 を以下の 2 群に注射

Agtra KO/Nephrin Cre $(+) /$ NEP25

Agtra KO/Nephrin Cre $(-) /$ NEP25

2 群とも中等度の蛋白尿（尿中アルブミン／クレアチニ ン 4.84 vs 8.08 ）を認めるが有意差なし

糸球体硬化（0.66 vs $0.82 ， 0 \sim 4$ 硬化スコアで比較）

に有意差なし

ネフリンの染色低下も両群で認めるが有意差なし

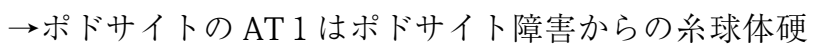
化に大きく影響しない。

(2)ARB はNEP25モデルにおいて糸球体硬化の進行を抑 えるか

NEB25マウスにARB を投与, ARB 投与群で有意に蛋 白尿は減少した (TP/Cr：66.6 20.7 vs $22.8 \pm 0.3 \mathrm{mg} /$ $\mathrm{mg}$, 注射 7 日後) ARB 投与群で糸球体硬化も有意に減 少した。

(0.83 \pm 0.36 vs $0.01 \pm 0.01$, 硬化スコア, 注射後21日) ARB 投与群でネフリンの染色は低下しなかった。

( $5.61 \pm 0.76$ vs $7.96 \pm 0.01,0$ to 8 scale)

Agtr 1 a KO/Nephrin Cre(+)/NEP25と Agtr 1 a KO/ Nephrin Cre (-)/NEP25にARB を投与し LMB 2 を注射 した 2 群と, NEP25単独のマウスにACEI を投与してみ たが, 同様の結果が得られた。コントロールとして, ヒ
ドララジンを投与した群ではそれらの効果は得られな かった。

(3)Ang II 持続投与によるアルブミン尿にポドサイトの選 択的AT 1 ブロックは影響を及ぼすか?

Agtr 1 a KO/Nephrin Cre(+)/NEP25と Agtr 1 a KO Nephrin Cre (-)/NEP25では, Ang II 投与下での血圧は 有意差を認めなかった。アルブミン尿は有意差がなかっ た。また，系球体硬化は認めず，ネフリンの減少も認め なかった。

\section{考察}

ポドサイト障害モデルであるNEP25マウスではARB でもACEIでもAngIIを抑えることにより，蛋白尿，ポ ドサイトの障害, 系球体硬化を抑えられる。ヒドララジ ンではその効果は認めず，血圧に関係なく腎保護作用を 認めている。ACEI も有効であるから, ARB の効果は, AT 1 以外のレセプターの活性化ではなく, AT 1 レセプ ターの阻害によるものである。In vivo と同様に, in vitro でポドサイトは機能的 AT 1 を発現している。さらに選 択的にポドサイトでAT 1 レセプターを発現するトラン スジェニックマウスでは，アルブミン尿やポドサイトの pseudocyst が増加し, 系球体硬化を引き起こす。

本研究ではポドサイト特異的 AT 1 の不活性化でベー スラインあるいはAng II に誘導される蛋白尿に影響を与 える結果が得られなかった。可能性としてAngIによる 刺激を与える期間や刺激の程度が違ったからかもしれな い。

このことより，われわれの今回行ったポドサイト特異 的 AT 1 KO の実験ではAng IIの投与で認めた一過性の 蛋白尿はポドサイトの局所の影響を反映しているもので はないことを示している。言い換えれば，ポドサイト以 外の細胞が系球体の透過性を変えたと考えられる。本研 究が示すことで重要な点は, AT 1 ブロッカーがポドサ イトを修復すること，それはポドサイトのAT1をブ ロックすることによらないということにある。Ang II は 輸出動脈の抵抗を増加, 輸入動脈抵抗を減少させること により糸球体濾過圧を上昇させる。これはGBM を通じ ての大分子の漏出を増加させる。

糸球体毛細血管内圧と糸球体硬化の関係についてはさ まざまな論文で報告されている。しかしながらこの関係 を結びつけるための分子的メカニズムはまだ確立されて いない。本研究では, NEP25モデルにおいて, ARBに より系球体毛細血管内圧が減少することが有効となって いることは, 過去の研究と比較して同様のものと言え る。 
日児腎誌 Vol.24 No.1

理論的にも, この考え方は輸出細動脈の選択的 AT 1 KO マウスでも確認できる。しかしながら, 輸出細 動脈の選択的Cre 遺伝子発現を制御するプロモーター 部分は現在においても知られていない。LMB 2 は標的の ポドサイトで，伸長因子 2 不活化し，蛋白合成を抑制す る。一つには，ポドサイト特異的AT 1 の不活性化によ る有効性を取り除くことはすなわちコントロール NEP

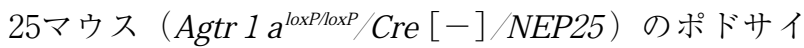
トに扮けるAT 1 蛋白の抑制にあたるかもしれない。今 回われわれは，AT 1 蛋白の定量はしなかったが, NEP 25マウスではLMB 2 の投与後 1 週間ではネフリン, WT 1, VEGF, シナプトポディンは減少しなかった。 さらにARB は LMB 2 を投与したコントロール NEP25マ ウスに打いて同様の効果を認めた。マウスはヒトと異な り，AT1レセプターにはA，B が存在する。AT 1 B の 腎臓における発現量はAT 1 A の0.5\%以下である。

近年, CrowleyらがAT1BレセプターはAT 1AKO マウスにおいてAng IIにより刺激されることを示唆して いる。

以前の報告で, AT 1 AKO マウスの腎ではAng II タイ プ 2 アンタゴニストの存在下で, Ang IIがオートラジオ グラフで結合しないことがわかっている。われわれの研 究では，ポドサイトAT 1 AKO あるいはLMB 2 投与に より, AT 1B は増加していなかった。ポドサイトの培 養細胞ではAT $1 \mathrm{~A}$ のみ検出される。さらに, ポドサイ トAT 1 AKO では血圧は正常である。それゆえに, レニ
ンやAng IIの発現増加は起こりえない。

残る可能性は糸球体内外のポドサイト以外の細胞にお ける，AT 1 の抑制による影響である。系球体以外とは， アルドステロン系を介した抑制つまり副腎皮質球状層も 含まれる。AngIに関与しないARB の作用，ARB,ACEI の抗酸化作用のようなものも影響を及ほしているかもし れない。

\section{紹介者のコメント}

この10年で，ポドサイトと糸球体硬化に関する分子レ ベル的解析に関する研究はどんどん進化している。本研 究もその一つであり, ポドサイトに発現しているAT 1 が，ポドサイト障害に関与するか否かをC Cre-loxP 特異 的細胞組換えを利用したKO マウスを用いて証明してい る。この論文を見て, 松阪氏の1990年代の研究が思い浮 かんだ。RAS 遺伝子に関するキメラ動物を作成し，AT $1 レ セ フ ゚ タ ー$ 陽性細胞の paracrine 的作用の解明に関す る研究である。本実験とは直接の関係はないが，興味の ある方はぜひ論文を読んでいただきたい。松阪氏は現在 まで多くの業績をあげ続けているが，講演を拝聴する と, exitingな内容なのに, いつも淡々として話される。 そして, その実験の組み立て方法, 得られた結果にはい つも驚かされる。これからも, 腎臓の分子学的メカニズ ムの最新情報を提供していっていただければと思う。

遺伝子学の専門用語が多く, 間違った表記も多々ある かと思いますが，ご容赦ください。 